travellers- were most severely affected at the highest camp on Golden Throne, though even here, when completely at rest, the inconvenience was comparatively slight. The ascent from this camp-probably about 3000 feet, without any exceptional difficulties-took $\delta \frac{3}{4}$ hours. In such a district as the Pennine Alps this distance would probably have been accomplished in half the time. It is therefore obvious that the difficulties in reaching such a point as K2 will be extremely great, though possibly not insuperable. Among these the weather will be one of the most serious. This, in the Alps, is frequently not good; in Baltistan, unless Mr. Conway's experience was exceptional, it is habitually abominable.

Much interesting information in regard to physical geology can be gleaned from this volume. The beautiful illustrations enable us to form a good idea of the magnificent snow peaks; the lower mountains, as a rule, seem to be more precipitous and shattered, more weird anc desolate than in the Alps (Fig. 1). The climatal conditions are probably favourable to rapid denudation; mud avalanches are frequent, sometimes on a gigantic scale; the fans of débris also are enormous. Mr. Conway's account of the alluvial deposits in the beds of the valleys, especially on the route to Leh, are most interesting (Fig. 3). These often make it difficult to

\title{
A NEW FORM OF OBJECT-GLASS MOUNTING.
}

$A$ MONG the numerous details in telescopic conA struction that have become of greater importance in consequence of the increase in size of refractors, may be mentioned that relating to the form of mounting of the object-glass, which plays a leading rôle in the good working of a telescope.

The chief difficulty which has to be overcome is the great dearth of substances which have the same coefficient of expansion as glass. For small objectives brass fastenings are used, but for larger discs these have been replaced by the adoption of steel, the coefficient of expansion of which more nearly approaches that of glass. In the latter case allowances have to be made for the difference of expansions of the two substances (glass and steel), and this is done by breaking the metallic band which encircles the objective, and connecting the two ends thus freed by means of one or more screws. In this way the pressure of the band on the circum. ference of the discs can be regulated by tightening or slackening the screws as the case may be, and the inequality of expansion or contraction can thus be counterbalanced.

If only one disc of glass were in question, the problem would be somewhat simple, but since an objective consists of two discs, and these of different kinds, each possessing its own special coefficient of expansion, the matter is distinctly complicated. WVith two discs it will be seen at once that the metallic ring may be made fast for one, while the other can be free to move, and therefore quite loose; this naturally raises numerous disturbances in the centering of the lenses.

The functions of a perfect cell are then, firstly, it must be capable of holding the lens firmly and without change of form ; while, secondly, it must be so arranged as to allow for the different changes brought about by temperature without disturbing the centering of the lenses.

To produce such a cell as this has been the object of FrG. 3.--Remains of Alluvium, Lama-yuru Valley

discover the limits to what glaciers have extended. At the present day the larger ice-streams seem to end at

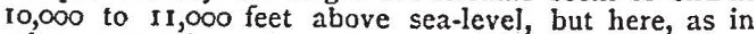
other mountain regions, they were once much greater. Mr. Conway mentions the occurrence of old moraines at various elevations down to about 6000 feet, and we cannot be certain that this is the lowest limit.

The volume contains, in addition to a map, three hundred illustrations, process-block reproductions of drawings by Mr.McCormick, some from photographs, and some from original sketches. They represent not only the scenery, but also incidents of travel, and greatly enhance the value of the book. It is worthy to take a place, for literary and artistic excellence, with Mr. Whymper's "Travels amongst the Great Andes of Ecuador," for it is a record of an adventurous journey, carefully planned and bravely effected, as well as a real contribution to knowledge. Clearly and pleasantly written, full of interesting information, not only on the geography, geology, and natural history, but also on the people, buildings, and customs of a rarely visited region, the book does honour to its genial and able author and to his companions in travel.

NO. 1287 , vOL. 50]
Dr. R. Steinheil's investigations ${ }^{1}$ and the following sum. mary contains his suggestions. The principle consists in leaving a space between the inside of the cell and the circumference of the two lenses, and placing rigidly between them blocks of particular substances and sizes, such that they compensate for the different expansions at work.

The amount a substance expands or contracts depends not only on its increase or decrease in temperature, but on its length; thus, for instance, a long rod when heated expands more than a short rod of the same substance. Making use of this fact, we may either assume the length of the blocks referred to above, and calculate of what substances it must be composed to give the exact coefficient of expansion required, or we may take any substance with a known coefficient of expansion, such as zinc, and determine the length it is required to be. The latter method, of course, by its simplicity commends itself, and if the length of the block be denoted by $l$ we have the formula

$$
l=\frac{\phi-\cdot \gamma}{\sigma-\phi}
$$

1 See "Ueber eine nette Art von Objektivfassungen" in Zcitsithift fï, Instruntentenkurie, Heft 5, p. 170, 1894 . 
which gives $l$ in terms of the coefficient of expansion of $(\phi)$ the cell material, $(\gamma)$ the glass, and $(\sigma)$ the material for the blocks. It will be seen from the formula that the shorter the blocks the more equal must be the coefficients of expansion of the glass and cell material, and also the greater the relative distance between the coefficients of expansion of the blocks and cell material.

Dr. Steinheil, as an example, determines the length of these blocks for an objective of $50 \mathrm{~cm}$. aperture, the lenses being composed of common flint silicate marked 0.544 in the Jena glass factory, and common crown silicate marked O.1022.

If the material for the blocks used be of zinc (coefficient of expansion $=\sigma=0^{\circ} 0 \operatorname{coo}_{2} 18$ ), then their length, adopting for the flint glass (544) the value $\gamma=0.00000788$ and for the cell material the value $\phi=0 \cdot 0000106$ I for their coefficients of expansion, is given by the equation

$$
l=\frac{1061-788}{2918-106 \mathrm{r}}=\frac{273}{1857}=0.147 \text {. }
$$

Similarly for the crown glass, the coefficient of which is 0.00000954 , we obtain the length of its blocks

$$
l=0.0576 \text {. }
$$

As the radii of the glass discs are the same and equal to $25 \mathrm{~cm}$., the lengths of the blocks for each of the lenses must be $0.147 \times 25 \mathrm{~cm}$. and $0.0576 \times 25 \mathrm{~cm}$. or $3^{\circ} 675 \mathrm{~cm}$. and $1.44 \mathrm{~cm}$.

Dr. Steinheil proposes that for each lens three blocks should be used and placed at intervals of $120^{\circ}$ round the circumference of the discs, the blocks fitting tightly between the discs and the sides of the cell. It might at first be thought that such tight-fitting as seems necessary could not be exactly enough done, but it is stated that accuracy in the length of the zinc block to $1 \mathrm{~mm}$. can be safely depended on, and the danger of strain by eliminating the disturbances of centering thereby reduced to a minimum.

That this new mounting for object-glasses has many points in its favour cannot be denied, but it is in such questions as these that we must look to the results after the method has been practically applied. Thus, practice would better settle the proper number of blocks for each lens; three seem at first sight somewhat too few, and might lead to local strains due to the weight of the lenses, whereas such strains must be avoided in any sort of cell.

V. J. S. LOCKYER.

\section{NOTES}

IVE are requested to state that a volume containing a memoir of the late Dr. Geo. J. Romanes, F.R.S., will be published. Those who possess letters of general interest witten by him are requested to forward them to Mrs. Romanes, St. Aldate's, Oxford. The letters will be returned directly their contents have been noted and copies made.

A Grace of the Senate of the University of Dublin has been passed, conferring the degree of Doctor of Science upon MIr. Daniel Morris, C.M.G., Assistant-Director of the Royal Gardens at kew.

Prof. Karl Gussenbauer, of Prague University, has been appointed to the chair of Surgery at Vienna, in succession to the late Prof. Billroth.

A REUTER telegram states that at a meeting of leading citizens held at Toronto on June 23 , it was unanimously decided to invite the British Association to hold the meeting there next year.

The Council of University College, Liverpool, have ap. pointed Dr. A. M. Paterson to the "Derby" Professorship of Anatomy, and Prof. R. IV. Boyce to the chair of Pathology recently endowed by Mr. George Holt.

No. I 287 , voL. 50]
UR. Augustus Schloesser, assistant to Prof. Henderson in the chemical department of the Glasgow and IVest of Scotland Technical College, has been appointed to the Principalship of the Storey Institute, Lancaster, rendered vacant by the resignation of Dr. G. S. Turpin.

A KINDLY and appreciative letter, by Prof. Poulton, F.R.S., on some incidents in the life of the late Prof. Romanes, ap. peared in the Times of June rg. The July number of Science Gossip contains an obituary notice of the lamented investigator, together with his portrait.

The Cracow Academy of Sciences have awarded the Copernicus Prize of five hundred florins, founded by the town of Cracow, to Prof. Louis Birkenmajer, for his work "Sur la temperature des lacs des Tatres." A prize of one thousand francs (Priz Majer) is offered for the best work on "La Climatologie des pays Polonais"; papers to be sent in before December 31,1896 .

A SEVERE earthquake disturbance was experienced at Oran, Algeria, at about one o'clock on the morning of the 19 th inst. The duration of the shock is said to have been four seconds.

A special meeting of the Chemical Society will be held this evening, at nine o'clock, at the Royal Institution, when Prof. Dewar will lecture on "Phosphorescence at very low temperatures."

THE meeting of the Museums Association, now being held in Dublin, was opened on Tuesday with an address by the President, Dr. Valentine Ball, C.B., F.R.S., on "The Museums of Dublin."

I $x$ the House of Commons on Tuesday, Colonel Howard Vincent asked the Home Secretary whether he had decided to adopt in the Metropolitan and City Police districts, and in the provinces, the recommendations of the committee appointed to inquire into the system of identifying criminals by measure. ment, invented by M. Bertillon, of Paris, and the finger-print test of Mr. Francis Galton; and, in such case, if, in order to facilitate research into the judicial antecedents of international criminals, the registers of measurements would be kept on the same plan as that adopted with such success in France, as also in other continental countries. In reply, Mr. Asquith said that the recommendations of the committee had been adopted, including the recommendations as to the mode of keeping the register.

In connection with the Antwerp Exposition, a Congress has been arranged, under the auspices of the Sociéte Royale de Geographie d'Anvers, having for its object the discussion of matters relating to the atmosphere. The Congress will be held on August 16,17 , and 18. The papers will be classified into two sections, one dealing with atmospheric movements, while the other is concerned with aerodynamics. The former section is divided into four parts as follows :(1) General theory of atmospheric currents and the causes which affect them. (2) Methods of observation at different altitudes. (3) Instruments of observation and for automatic registration. (4) Maps of permanent and of variable atmospheric currents, and a comparison of them with ocean currents. In the aerodynamic section the subjects dealt with will be:(I) The measurement of the velocity of wind. The action of wind on a plane normal surface and on an inclined surface will be considered, and the friction of air. Experimental apparatus is also included in this division, and the effects of wind on buildings, bridges, towers, sc. Aeroplanes, windmills, and turbines are classified under the motive power of wind, while transport by land, sea, and air are arranged in a sub.group of questions relating to the resisting power of air. The subjects of the second part of the second section are the special applica. 